African Crop Science Journal by African Crop Science Society is licensed under a Creative Commons Attribution 3.0 Uganda License. Based on a work at www.ajol.info/ and www.bioline.org.br/cs DOI: http://dx.doi.org/10.4314/acsj.v24i2.2

\title{
EFFECT OF AMBIENT LEVELS OF OZONE ON PHOTOSYNTHETIC COMPONENTS AND RADICAL SCAVENGING SYSTEM IN LEAVES OF AFRICAN COWPEA VARIETIES
}

\author{
R. TETTEH, M. YAMAGUCHI ${ }^{1}$ and T. IZUTA $^{2}$ \\ United Graduate School of Agricultural Science, Tokyo University of Agriculture and Technology, Fuchu, \\ Tokyo 183-8509, Japan \\ ${ }^{1}$ Graduate School of Fisheries and Environmental Sciences, Nagasaki University, 1-14 Bunkyo-machi, \\ Nagasaki 852-8521, Japan \\ ${ }^{2}$ Institute of Agriculture, Tokyo University of Agriculture and Technology, Fuchu, Tokyo 183-8509, Japan \\ Corresponding author: izuta@cc.tuat.ac.jp
}

(Received 16 December, 2015; accepted 29 April, 2016)

\begin{abstract}
Tropospheric ozone $\left(\mathrm{O}_{3}\right)$, a main component of photochemical oxidants, adversely affects not only human health but also vegetation. To clarify the long-term effects of ambient levels of tropospheric ozone $\left(\mathrm{O}_{3}\right)$ on photosynthetic components and radical scavenging system in the leaves of cowpea (Vigna unguiculata L.), two African varieties, Blackeye and Asontem, were grown in open-top chambers and exposed to filtered air (FA), non-filtered air (NF) or non-filtered air with additional $\mathrm{O}_{3}$ of approximately $50 \mathrm{nl} \mathrm{l}^{-1}$. Ambient levels of $\mathrm{O}_{3}$ significantly reduced chlorophyll concentration, quantum yield and activity of ribulose 1,5-bisphosphate carboxylase/oxygenase (Rubisco), thus contributing to the reduction in net photosynthetic rate at the reproductive growth stage of both varieties; with no significant variety difference in the sensitivity to $\mathrm{O}_{3}$. The $\mathrm{O}_{3}$-induced significant reduction in catalase activity was observed in Blackeye at vegetative and reproductive growth stages; and in Asontem at reproductive growth stage. On the other hand, exposure to $\mathrm{O}_{3}$ significantly increased ascorbate peroxidase activity in Blackeye at reproductive stage and did not significantly affect that in Blackeye at vegetative growth stage and that in Asontem at both growth stages. At reproductive growth stage, activities of monodehydroascorbate reductase and glutathione reductase were significantly increased by the exposure to $\mathrm{O}_{3}$ in both varieties. The results obtained in this study suggest that, although ascorbate peroxidase, monodehydroascorbate reductase and glutathione reductase played important roles in scavenging $\mathrm{O}_{3}$-induced reactive oxygen species in the leaves, radical scavenging ability of these enzymes is not sufficient to avoid detrimental effects of ambient levels of $\mathrm{O}_{3}$ on photosynthesis in both African cowpea varieties.
\end{abstract}

Key Words: Chlorophyll, Rubisco, Tropospheric ozone, Vigna unguiculata

\section{RÉSUMÉ}

L'ozone troposphérique $\left(\mathrm{O}_{3}\right)$, un composant essential des oxydants photochimiques, a des effets pervers sur la santé humaine et la végétation. Afin de clarifier les effets à long-terme des niveaux ambiants de l'ozone troposphérique $\left(\mathrm{O}_{3}\right)$ sur les composantes de la photosynthèse et le système d'épuration des feuilles du niébé (Vigna unguiculata L.), deux variétés de niébé Africain, Blackeye et Asontem, ont été cultivées dans une chambre d'expérimentation et exposées à l'air filtré (FA), l'air non filtré (NF) ou air non filtré additionné de $\mathrm{O}_{3}$ à $50 \mathrm{nl}$ $1^{-1}$. Les niveaux ambiants d' $\mathrm{O}_{3}$ ont réduit de façon significative la concentration en chlorophylle, le rendement en quantum et l'activité de ribulose 1,5-bisphosphate carboxylase/oxygenase (Rubisco), contribuant ainsi à la réduction du taux photosynthétique net au stade reproductif des deux variétés; il n'y a pas eu de différence significative 
dans la sensibilité des variétés à $\mathrm{O}_{3}$. Une réduction significative induite par l'O $\mathrm{O}_{3}$ dans l'activité de catalase a été observée aux stades végétatif et reproductif chez la variété Blackeye; et au stade reproductif chez Asontem. D'autre part, l'exposition à l' $\mathrm{O}_{3}$ a augmenté de façon significative l' activité de l'ascorbate peroxidase seulement au stade reproductif chez Blackeye mais aux deux stades végétatif et reproducteur chez la variété Asontem. Au stade reproductif, l'activité de monodehydroascorbate réductase et de glutathione réductase ont été augmentée de façon significative par l'exposition à l' $\mathrm{O}_{3}$ chez les deux variétés. Les résultats obtenus dans cette étude suggèrent que malgré le role important que jouent ascorbate peroxidase, monodehydroascorbate réductase et glutathione réductase dans l'épuration dans les feuilles des espèces à oxygène réactif induit par l' $\mathrm{O}_{3}$, l'habileté d'épuration de ces enzymes n'est pas assez pour éviter les effets nocifs des niveaux ambiants d' $\mathrm{O}_{3}$ sur la photosynthèse chez les variétés de niébé Africain.

Mots Clés: Chlorophylle, Rubisco, ozone troposphérique, Vigna unguiculata

\section{INTRODUCTION}

Tropospheric ozone $\left(\mathrm{O}_{3}\right)$, the main component of photochemical oxidants, adversely affects not only human health, but also the quality and quantity of vegetation (Fuhrer, 2009; Emberson et al., 2013). Booker et al. (2009) indicated that current atmospheric $\mathrm{O}_{3}$ concentrations are sufficiently high to damage sensitive species of native vegetation and cultivated plants worldwide. Globally, most of the tropospheric $\mathrm{O}_{3}$ comes from photochemical reactions of methane $\left(\mathrm{CH}_{4}\right)$, volatile organic compounds (VOCs) and nitrogen oxides (NOx), which are largely from anthropogenic emissions (Ainsworth et al., 2012). Africa is an important source region of $\mathrm{O}_{3}$ precursors, and emits a large amount from biomass burning (CO, NOx and VOCs) associated with savanna and forest fires, which takes place during the dry and monsoon periods, as well as with agricultural waste and domestic biofuel combustion (Sauvage et al., 2007). The World Meteorological Organisation modeled monthly mean $\mathrm{O}_{3}$ concentrations around $36 \mathrm{nl} \mathrm{l}^{-1}$ (ppb) during day-time measurements in West Africa (WMO, 2011). With lack of facilities to monitor the atmospheric concentration of $\mathrm{O}_{3}$, it is important to investigate its effects on African crops to ascertain its present and future impacts on crop productivity, and breed crops with tolerance to elevated $\mathrm{O}_{3}$ concentration for food security in Africa.

Numerous studies have shown that $\mathrm{O}_{3}$ affects physiological functions and growth of plants, by causing oxidative stress and damaging the photosynthetic apparatus (Baier et al., 2005).
Ozone induces a variety of physiological and biochemical alterations at the leaf level, including reduction in photosynthesis, stomatal closure, chlorophyll degradation and premature senescence, with or without visible foliar injury (Pina and Moraes, 2010). During normal gas exchange by plants, $\mathrm{O}_{3}$ enters the leaf through stomata (Baier et al., 2005), and once inside the sub-stomatal cavity, it reacts with the extracellular environment and generates reactive oxygen species (ROS), causing oxidative stress (Pell et al., 1997; Baier et al., 2005). To combat oxidative stress, plants employ several defense mechanisms (Blokhina et al., 2003), which are operated by scavenging ROS once they are formed. Some of the proposed components of these oxidative defense systems are enzymes such as superoxide dismutase (SOD), catalase (CAT) and ascorbate peroxidase (APX); and low molecular mass scavengers such as ascorbic acid, phenolic compounds and glutathione (Blokhina et al., 2003). Heath (2008) noted that it is still a matter of debate whether a high detoxification potential against ROS or stress-induced detoxification processes are actually responsible for $\mathrm{O}_{3}$-tolerance. In soybean, detoxification capacity of $\mathrm{ROS}$ in the $\mathrm{O}_{3}$-tolerant cultivar exceeded that in the $\mathrm{O}_{3}$-sensitive cultivar (Cheng et al., 2007). To evaluate the present and future impacts of $\mathrm{O}_{3}$ on crop productivity and breed crops with tolerance for elevated $\mathrm{O}_{3}$ concentration for food security in Africa, therefore, it is important to ascertain whether detoxification capacity could be related to the sensitivity to $\mathrm{O}_{3}$ of physiological functions such as photosynthesis in African crops. 
Cowpea is one of the most important indigenous African legume crops, especially in West and Central Africa (Langyintuo et al., 2003). It is regarded as a key source of protein for the urban and rural people, and plays an important role as a cash crop (Langyintuo et al., 2003). Most cowpeas are grown on the African continent, particularly in Nigeria and Niger which accounts for $72 \%$ of the world cowpea production (FAOSTAT, 2012). Addo-Quaye et al. (2011) reported average cowpea grain yield ranging from 0.8 to 1.3 tonnes per hectare in Ghana. In our previous study (Tetteh et al., 2015), the exposure to $\mathrm{O}_{3}$ reduced growth, net photosynthesis and yield of two African cowpea varieties (Blackeye and Asontem), but the mechanisms underlying these reductions were not clearly understood. Umponstira et al. (2006) found that short-term exposure (1 week) of 7-dayold cowpea plants to $\mathrm{O}_{3}$ at 40 and $70 \mathrm{ppb}$, showed higher activities of SOD, CAT and APX than those of the 21-day-old plants and total ascorbate concentrations. However, there is no information on the long-term effects of ambient levels of $\mathrm{O}_{3}$ on biochemical components of cowpea. In the present study, therefore, we investigated the long-term effects of ambient levels of $\mathrm{O}_{3}$ on photosynthetic components and radical scavenging system of two African cowpea varieties.

\section{MATERIALS AND METHODS}

Plant materials and experimental site. Seeds of two cowpea varieties (Blackeye and Asontem), which are the most widely cultivated varieties in Ghana, were obtained from the Department of Crop Science, University of Ghana (Legon, Ghana). Seeds were sown on 29 June 2014 in plastic pots (2-L) filled with sandy soil (Kanuma pumice soil) in three hills (two seeds per hill); and later thinned to one plant per pot. The two varieties were cultivated from 29 June to 4 October 2014 in open-top chambers located at the experimental farm of Tokyo University of Agriculture and Technology (Fuchu, Tokyo, Japan). Hyponex compound liquid fertiliser (NPK $6-10-5 ; 4 \mathrm{ml}$ in $1 \mathrm{~L}$ of water) was applied at a rate of $200 \mathrm{ml}$ per pot, 9 days after sowing, and at 2week intervals on 25 July, 8 August and 22 August during the cultivation period. The two varieties were watered daily throughout the cultivation period.

Gas treatments and experimental design. Treatments included two cowpea varieties, three gas treatments, namely air filtered to remove $\mathrm{O}_{3}$ (FA), unfiltered air (NF); and unfiltered air supplemented with approximately $50 \mathrm{ppb} \mathrm{O}_{3}$ $\left(\mathrm{NF}+\mathrm{O}_{3}\right)$. Nine open-top chambers $(0.6 \mathrm{~m} \times 0.6 \mathrm{~m}$ $\times 1 \mathrm{~m}$ high), each assigned to one of the three gas treatments ( 3 replications), were arranged in a randomised complete block design. For each variety, four plants were used per chamber. The two cowpea varieties were grown in the opentop chambers and exposed to air that was either filtered to remove $\mathrm{O}_{3}(\mathrm{FA})$, unfiltered (NF) or unfiltered and supplemented with approximately $50 \mathrm{ppb} \mathrm{O}_{3}$ generated by an electrical discharge generator (SO-03UN, Hamanetsu Co., Hamamatsu, Japan) for $5 \mathrm{hr}$, from 11:00 to 16:00 each day $\left(\mathrm{NF}+\mathrm{O}_{3}\right)$. These gas treatments lasted 84 days, from 12 July to 4 October 2014. The generated $\mathrm{O}_{3}$ was passed through water-trap to remove nitrogen by-products, before being injected into the $\mathrm{NF}+\mathrm{O}_{3}$ chambers. Plants of each variety were rotated within the chamber every week and among chambers at 2-week intervals, to minimise variation among plants and gas treatments.

Monitoring of climatic parameters and ozone concentrations. Air temperature and relative humidity in the 9 open-top chambers were monitored using a thermo recorder (TR-72Ui; T \& D Corp.), comprising of a sensor and logger, throughout the cultivation period (Table 1). The concentrations of $\mathrm{O}_{3}$ in the 9 open-top chambers were monitored with an $\mathrm{O}_{3}$ monitor (model 1150; Dylec, Ibaraki, Japan). A voltage recorder (VR71; T \& D Corp., Nagano, Japan) was used for recording $\mathrm{O}_{3}$ concentrations in the 9 open-top chambers, throughout the cultivation period. The sum of all hourly mean $\mathrm{O}_{3}$ concentrations (SUM0), was calculated using hourly mean $\mathrm{O}_{3}$ concentrations. The accumulated $\mathrm{O}_{3}$ over a threshold of $40 \mathrm{ppb}$ (AOT40) was calculated as the sum of differences between the hourly mean $\mathrm{O}_{3}$ concentration and $40 \mathrm{ppb}$ when the hourly mean $\mathrm{O}_{3}$ concentration exceeded $40 \mathrm{ppb}$. 
Measurement of net photosynthetic rate. Net photosynthetic rate $(A)$ of two cowpea varieties was measured on 2-5 August 2014 (21-24 days after exposure to $\mathrm{O}_{3}$, DAE) on the $2^{\text {nd }}$ or $3^{\text {rd }}$ fully expanded leaves from the bottom, and on 27-30 August (46-49 DAE) on the $5^{\text {th }}$ or $6^{\text {th }}$ fully expanded leaves from nine plants per treatment of each variety using a portable photosynthetic measurement system (LI-6400; LiCor, Lincoln, NE, USA). During the measurements, atmospheric $\mathrm{CO}_{2}$ concentrations, air temperature, relative humidity, flow rate and photosynthetic photon flux density in the leaf chambers were maintained at $390 \mu \mathrm{mol} \mathrm{mol}{ }^{-1}, 25 \pm 0.5^{\circ} \mathrm{C}, 70 \pm 5 \%, 650 \mu \mathrm{mol}$ $\mathrm{s}^{-1}$ and $1500 \mu \mathrm{mol} \mathrm{m} \mathrm{m}^{-2} \mathrm{~s}^{-1}$, respectively.

Chlorophyll fluorescence. Fluorescence measurements were taken on the $2^{\text {nd }}$ or $3^{\text {rd }}$ fullyexpanded leaves from the bottom on 2-5 August 2014 (21-24 DAE), corresponding to the vegetative growth stage; and on the $5^{\text {th }}$ or $6^{\text {th }}$ fullyexpanded leaves from the bottom on 27-30 August (46-49 DAE), coinciding with the reproductive growth stage of the two cowpea varieties. The fluorescence measurements were made on 3 plants per chamber ( 9 plants per treatment) of each variety, using a portable photosynthetic measurement system (LI-6400; Li-Cor, Lincoln, NE, USA), fitted with an integral fluorescence chamber. Prior to measurements, each leaf was dark-adapted for approximately $1 \mathrm{hr}$. Darkadapted measurements of minimal fluorescence $\left(F_{0}\right)$, maximal fluorescence $(F m)$ and variable fluorescence $(F v)$; as well as the $F v / F m$ ratio were obtained. Then, the leaves were allowed to attain equilibrium for 30 minutes at a photon flux density of $800 \mu \mathrm{mol} \mathrm{m} \mathrm{m}^{-2} \mathrm{~s}^{-1}$. Measurements of minimal fluorescence of a light-adapted leaf $\left(F_{0}{ }^{\prime}\right)$, maximal fluorescence $\left(F m^{\prime}\right)$, steady-state fluorescence $(F s)$ and variable fluorescence $\left(F v^{\prime}\right)$ were taken. From these measurements, photochemical $(q P)$, non-photochemical $(q N)$ quenching and maximum quantum efficiency of PSII photochemistry at 800 $\mu \mathrm{mol} \mathrm{m} \mathrm{m}^{-2} \mathrm{~s}^{-1}\left(F v^{\prime} / F m^{\prime}\right.$ ratio) were obtained and quantum yield $\left(\Phi_{P S I I}\right)$ was computed.

Leaf sampling. For the measurements of photosynthetic components, activity of reactive oxygen species (ROS) scavenging enzymes and concentration of antioxidants, the $2^{\text {nd }}$ or $3^{\text {rd }}$ and $5^{\text {th }}$ or $6^{\text {th }}$ fully-expanded leaves from the bottom of plants were harvested on 6 August (25 DAE) and 1 September (51 DAE) 2014, respectively. Immediately after harvest, the leaves were frozen in liquid nitrogen and stored at $-80^{\circ} \mathrm{C}$ in a freezer. The measurements were made on 3 plants per chamber ( 9 plants per treatment) of each variety for each sampling date. With regards to ascorbate peroxidase (APX) activity, the measurement was conducted immediately after freezing leaf samples in liquid nitrogen. All measurements were conducted using a spectrophotometer (UV-1240, Shimadzu, Japan).

Rubisco activity and chlorophyll. Rubisco activity in the leaves was determined using the procedure of Tissue et al. (1993) and has been described in detail by Inada et al. (2008). The concentration of chlorophyll was determined by the method of Barnes et al. (1992) and has been described in detail by Inada et al. (2008).

Activity of Reactive Oxygen Species. To measure ascorbate peroxidase activity (APX), $50 \mathrm{mg}$-leaf sample was homogenised in a mortar and pestle containing some amount (approximately $0.5 \mathrm{~g}$ ) of quartz sand with PVPP and liquid nitrogen. The activity of APX was measured using the procedure of Inada et al. (2008).

The activities of superoxide dismutase (SOD), catalase (CAT), monodehydroascorbate reductase (MDAR), dehydroascorbate reductase (DHAR) and glutathione reductase (GR) were measured by the methods of Inada et al. (2008). For the measurement of activities of SOD, CAT, GR, MDAR and DHAR, $100 \mathrm{mg}$ leaf samples stored at $-80{ }^{\circ} \mathrm{C}$ were homogenised to fine powders with a mortar and pestle containing some amount of quartz sand and PVPP in liquid nitrogen. Then $1 \mathrm{ml}$ of extraction buffer prepared from $100 \mathrm{mM} \mathrm{KH}_{2} \mathrm{PO}_{4}(\mathrm{pH} 7.8)$ was used. The crude homogenate was centrifuged at $16,000 \mathrm{~g}$ for 10 minutes at $4{ }^{\circ} \mathrm{C}$. Subsequently, $500 \mu \mathrm{l}$ of the supernatant was added to $2 \mathrm{ml}$ of the extraction buffer, which was applied to the desalting column for the elution of sample. Subsequently, $3.5 \mathrm{ml}$ of the extraction buffer was used for elution of sample into glass bottles for the measurement of enzyme activities. 
Antioxidant concentration. The concentrations of ascorbate and glutathione were measured according to the procedure of Inada et al. (2008). For total ascorbate, $30 \mathrm{mg}$ of leaf sample stored at $-80^{\circ} \mathrm{C}$ was homogenised in a mortar and pestle containing some amount of quartz sand, without PVPP with liquid nitrogen. Then, $1.5 \mathrm{ml}$ of extraction buffer $(5 \%$ (w/v) metaphosphoric acid) was added to dissolve the sample. The sample was then centrifuged at $15,000 \mathrm{~g}$ for 10 minutes at $4^{\circ} \mathrm{C}$ to obtain the supernatant. Subsequently, part of the supernatant was stored for the measurement of glutathione in an ultra-cold freezer kept at $-80^{\circ} \mathrm{C}$.

Data analyses. Statistical analyses were conducted using the Statistical Package for the Social Sciences (SPSS). Statistics 21 (IBM, Chicago, IL, USA). Two-way analysis of variance (ANOVA) was used to test the effects of gas treatment and cowpea variety. When a significant interaction between gas treatment $\left(\mathrm{O}_{3}\right)$ and cowpea variety was detected, Tukey's HSD test was performed to identify significant differences among the six values.

\section{RESULTS}

Environmental parameters. Table 1 presents air temperature, relative air humidity, average $\mathrm{O}_{3}$ concentration, SUM0 and AOT40 of $\mathrm{O}_{3}$ in each gas treatment inside the open-top chambers during the exposure period. The highest daily maximum air temperature was detected in August $\left(40.6{ }^{\circ} \mathrm{C}\right)$ and the minimum in the same month $\left(20.5^{\circ} \mathrm{C}\right)$ (Table 1$)$. The average daily relative air humidity in all the chambers was in the range of $37.4-97.3 \%$ during the experimental period. The highest average $\mathrm{O}_{3}$ concentration between 11:00 and 16:00 was observed in the $\mathrm{NF}+\mathrm{O}_{3}$ treatment (88 ppb), while the FA treatment recorded the lowest value of $18 \mathrm{ppb}$. The highest hourly $\mathrm{O}_{3}$ concentration was $152 \mathrm{ppb}$ in the $\mathrm{NF}+\mathrm{O}_{3}$ treatment. The highest SUM0 and AOT40 were 61.3 and $13.0 \mathrm{ml} \mathrm{l}^{-1} \mathrm{~h}(\mathrm{ppm} \mathrm{h})$, respectively in the $\mathrm{NF}+\mathrm{O}_{3}$ treatment.

Photosynthetic components. Table 2 shows the effects of $\mathrm{O}_{3}$ on net photosynthetic rate $(A)$ and chlorophyll $a$ fluorescence parameters, at vegetative (21 DAE) and reproductive (46 DAE) growth stages in the two cowpea varieties (Blackeye and Asontem). The exposure to $\mathrm{O}_{3}$ had no significant effects on $A, F v / F m, F v^{\prime} / F m^{\prime}, q P$, $q N, N P Q$ and $\Phi_{P S I I}$ at $21 \mathrm{DAE}$, in both varieties. However, at $46 \mathrm{DAE}$, the exposure to $\mathrm{O}_{3}$ reduced $(\mathrm{P}<0.05) A, F v^{\prime} / F m^{\prime}, q P$ and $\Phi_{P S I}$ in both varieties. At 21 DAE, $N P Q$ in Asontem was significantly higher than that in Blackeye. At $46 \mathrm{DAE}, q P, q N$, $N P Q$ and $\Phi_{P S I I}$ were significantly higher in Asontem than in Blackeye. No significant interaction between gas treatment and variety was found in $A$ and chlorophyll $a$ fluorescence parameters at 21 and $46 \mathrm{DAE}$.

Table 3 presents the effects of $\mathrm{O}_{3}$ on chlorophyll concentration and the ratio of chlorophyll $a$ concentration to chlorophyll $b$ concentration $(a / b$ ratio) in the leaves of the two cowpea varieties, at vegetative (25 DAE) and reproductive (51 DAE) growth stages. Chlorophyll $a, b$ and total concentrations were reduced by exposure to $\mathrm{O}_{3}$ at 25 and $51 \mathrm{DAE}$. Furthermore, chlorophyll $a / b$ ratio was significantly reduced by the exposure to $\mathrm{O}_{3}$ at 51 DAE. At 25 DAE, Chlorophyll $b$ concentration and $a / b$ ratio in Asontem were significantly higher and lower than those in Blackeye, respectively. At $51 \mathrm{DAE}$, concentration of chlorophyll $a, b$ and $a+b$ in Asontem were significantly higher than those in Blackeye. There was no significant interaction between gas treatment and variety in chlorophyll concentration and $a / b$ ratio, at 25 and 51 DAE.

Table 4 shows the effect of $\mathrm{O}_{3}$ on the activity of ribulose 1,5-bisphosphate carboxylase/ oxygenase (Rubisco) in the leaves of two cowpea varieties, at vegetative (25 DAE) and reproductive (51 DAE) growth stages. The initial activity, total activity and activation state of Rubisco in both varieties were not significantly affected by the exposure to $\mathrm{O}_{3}$, at 25 DAE. At 51 DAE, however, the initial and total Rubisco activities were significantly reduced by the exposure to $\mathrm{O}_{3}$ with no significant effect of $\mathrm{O}_{3}$ on the activation state in both varieties. No significant difference in Rubisco activity was observed between the varieties. Furthermore, there was no significant interaction between gas treatment and variety in the activity and activation state of Rubisco, at 25 and 51 DAE. 
TABLE 1. Air temperature, relative air humidity, average $\mathrm{O}_{3}$ concentration, SUMO and $A O T 40$ of $\mathrm{O}_{3}$ in each gas treatment

\begin{tabular}{|c|c|c|c|c|c|c|c|c|}
\hline \multirow[t]{2}{*}{ Period (2014) } & \multicolumn{4}{|c|}{ Air temperature $\left({ }^{\circ} \mathrm{C}\right)$} & \multicolumn{4}{|c|}{ Relative air humidity (\%) } \\
\hline & 24 hr-Ave & 12 hr-Ave ${ }^{a}$ & Daily max. ${ }^{b}$ & Daily $\min .^{c}$ & 24 hr-Ave & $12 \mathrm{hr}-\mathrm{Ave}^{\mathrm{a}}$ & Daily max. ${ }^{b}$ & Daily $\min .{ }^{c}$ \\
\hline 12-31 July & 27.4 & 31.3 & 38.7 & 25.2 & 69.5 & 55 & 80.6 & 41.8 \\
\hline 1-31 August & 28.8 & 32.7 & 40.6 & 20.5 & 73.5 & 62.4 & 97.3 & 37.4 \\
\hline \multirow[t]{2}{*}{ Period (2014) } & Treatment & \multicolumn{4}{|c|}{$\mathrm{O}_{3}$ concentration $(\mathrm{ppb})$} & \multirow{2}{*}{$\begin{array}{c}\text { SUM0 } \\
\text { (ppm hr) }\end{array}$} & \multirow{2}{*}{$\begin{array}{r}\text { AOT40 } \\
\text { (ppm hr) }\end{array}$} & \\
\hline & & 24 hr-Ave & 12 hr-Ave ${ }^{a}$ & 5 hr-Ave ${ }^{d}$ & Highest 1-hre & & & \\
\hline \multirow[t]{3}{*}{12 July - 31 August } & FA & 14 & 15 & 18 & 61 & 15.3 & 0.1 & \\
\hline & NF & 25 & 32 & 35 & 121 & 28.1 & 3.1 & \\
\hline & $\mathrm{NF}+\mathrm{O}_{3}$ & 35 & 53 & 88 & 152 & 61.3 & 13 & \\
\hline
\end{tabular}


TABLE 2. Effect of $\mathrm{O}_{3}$ on net photosynthetic rate $(A)$ and chlorophyll a fluorescence parameters of two cowpea varieties at 21 and 46 days after exposure (DAE) to $\mathrm{O}_{3}$

\begin{tabular}{|c|c|c|c|c|c|c|c|c|c|}
\hline Growth stage & Variety & Gas treatment & $\mathrm{A}\left(\mu \mathrm{mol} \mathrm{CO} \mathrm{Cm}^{-2} \mathrm{~s}^{-1}\right)$ & $\mathrm{Fv} / \mathrm{Fm}$ & Fv'/Fm' & $\mathrm{qP}$ & $\mathrm{qN}$ & NPQ & $\Phi_{\mathrm{PSI}}$ \\
\hline \multirow[t]{9}{*}{$21 \mathrm{DAE}$} & \multirow[t]{3}{*}{ Blackeye } & FA & $14.33(0.60)$ & $0.687(0.042)$ & $0.65(0.08)$ & $0.64(0.03)$ & $0.83(0.02)$ & $1.83(0.03)$ & $0.25(0.03)$ \\
\hline & & NF & $11.25(3.67)$ & $0.678(0.041)$ & $0.60(0.09)$ & $0.60(0.06)$ & $0.85(0.03)$ & $2.00(0.23)$ & $0.21(0.06)$ \\
\hline & & $\mathrm{NF}+\mathrm{O}_{3}$ & $10.61(3.17)$ & $0.671(0.020)$ & $0.62(0.10)$ & $0.52(0.11)$ & $0.86(0.04)$ & $2.12(0.42)$ & $0.17(0.07)$ \\
\hline & \multirow[t]{3}{*}{ Asontem } & FA & $9.25(2.90)$ & $0.692(0.029)$ & $0.61(0.09)$ & $0.51(0.08)$ & $0.88(0.02)$ & $2.43(0.06)$ & $0.17(0.04)$ \\
\hline & & NF & $10.30(2.46)$ & $0.698(0.041)$ & $0.61(0.09)$ & $0.53(0.03)$ & $0.86(0.04)$ & $2.22(0.32)$ & $0.19(0.04)$ \\
\hline & & $\mathrm{NF}+\mathrm{O}_{3}$ & $10.04(0.20)$ & $0.680(0.047)$ & $0.61(0.10)$ & $0.54(0.03)$ & $0.87(0.02)$ & $2.28(0.23)$ & $0.18(0.01)$ \\
\hline & \multirow[t]{3}{*}{ ANOVA } & Treatment(T) & n.s. & n.s. & n.s. & n.s. & n.s. & n.s. & n.s. \\
\hline & & Variety $(\mathrm{V})$ & n.s. & n.s. & n.s. & n.s. & n.s. & * & n.s. \\
\hline & & $\mathrm{T} \times \mathrm{V}$ & n.s. & n.s. & n.s. & n.s. & n.s. & n.s. & n.s. \\
\hline \multirow[t]{9}{*}{$46 \mathrm{DAE}$} & \multirow[t]{3}{*}{ Blackeye } & FA & $23.10(3.10)$ & $0.797(0.011)$ & $0.57(0.07)$ & $0.68(0.03)$ & $0.73(0.05)$ & $1.57(0.33)$ & $0.37(0.04)$ \\
\hline & & NF & $21.81(1.76)$ & $0.790(0.017)$ & $0.52(0.03)$ & $0.63(0.04)$ & $0.74(0.03)$ & $1.68(0.19)$ & $0.33(0.04)$ \\
\hline & & $\mathrm{NF}+\mathrm{O}_{3}$ & $10.77(1.62)$ & $0.800(0.009)$ & $0.46(0.01)$ & $0.38(0.06)$ & $0.81(0.02)$ & $1.94(0.14)$ & $0.17(0.02)$ \\
\hline & \multirow[t]{3}{*}{ Asontem } & FA & $24.57(3.89)$ & $0.808(0.003)$ & $0.55(0.03)$ & $0.69(0.03)$ & $0.74(0.04)$ & $1.60(0.24)$ & $0.38(0.04)$ \\
\hline & & NF & $24.53(2.11)$ & $0.800(0.008)$ & $0.53(0.03)$ & $0.67(0.02)$ & $0.75(0.05)$ & $1.67(0.31)$ & $0.36(0.03)$ \\
\hline & & $\mathrm{NF}+\mathrm{O}_{3}$ & $7.36(0.82)$ & $0.794(0.007)$ & $0.46(0.01)$ & $0.47(0.04)$ & $0.81(0.02)$ & $2.04(0.16)$ & $0.22(0.01)$ \\
\hline & \multirow[t]{3}{*}{ ANOVA } & Treatment(T) & $* * *$ & n.s. & $* *$ & $* * *$ & n.s. & n.s. & $* * *$ \\
\hline & & Variety (V) & n.s. & n.s. & n.s. & * & $* *$ & * & * \\
\hline & & $\mathrm{T} \times \mathrm{V}$ & n.s. & n.s. & n.s. & n.s. & n.s. & n.s. & n.s. \\
\hline
\end{tabular}


TABLE 3. Effect of $\mathrm{O}_{3}$ on the chlorophyll concentration and the ratio of chlorophyll a concentration to chlorophyll b concentration (a/ $\mathrm{b}$ ratio) in the leaves of two cowpea varieties at 25 and 51 days after exposure (DAE) to $\mathrm{O}_{3}$

\begin{tabular}{|c|c|c|c|c|c|c|}
\hline \multirow[t]{2}{*}{ Growth stage } & \multirow[t]{2}{*}{ Variety } & \multirow[t]{2}{*}{ Gas treatment } & \multicolumn{3}{|c|}{ Chlorophyll concentration $\left(\mu \mathrm{g} \mathrm{cm}^{-2}\right)$} & \multirow[t]{2}{*}{ a/b ratio } \\
\hline & & & $a$ & $\mathrm{~b}$ & $a+b$ & \\
\hline \multirow[t]{9}{*}{$25 \mathrm{DAE}$} & Blackeye & FA & $30.11(1.58)$ & $9.63(0.33)$ & $39.74(1.89)$ & $3.14(0.07)$ \\
\hline & & NF & $30.67(5.84)$ & $9.78(1.12)$ & $40.46(6.94)$ & $3.07(0.22)$ \\
\hline & & $\mathrm{NF}+\mathrm{O}_{3}$ & $22.16(2.13)$ & $6.80(0.59)$ & $28.97(2.71)$ & $3.22(0.06)$ \\
\hline & Asontem & FA & $30.20(2.36)$ & $10.16(0.52)$ & $40.36(2.74)$ & $2.96(0.16)$ \\
\hline & & NF & $28.93(6.58)$ & $10.44(1.73)$ & $39.37(8.17)$ & $2.78(0.25)$ \\
\hline & & $\mathrm{NF}+\mathrm{O}_{3}$ & $25.32(0.43)$ & $8.84(0.16)$ & $34.15(0.50)$ & $2.84(0.12)$ \\
\hline & ANOVA & Treatment(T) & * & ** & * & n.s. \\
\hline & & Variety $(\mathrm{V})$ & n.s. & * & n.s. & ** \\
\hline & & $\mathrm{T} \times \mathrm{V}$ & n.s. & n.s. & n.s. & n.s. \\
\hline \multirow[t]{9}{*}{$51 \mathrm{DAE}$} & Blackeye & FA & $32.75(2.78)$ & $9.71(0.58)$ & 42.47 (3.35) & $3.40(0.10)$ \\
\hline & & $N F$ & $33.44(2.54)$ & $10.13(0.35)$ & $43.58(2.81)$ & $3.28(0.16)$ \\
\hline & & $\mathrm{NF}+\mathrm{O}_{3}$ & $24.14(0.88)$ & $7.65(0.38)$ & $31.79(1.26)$ & $3.16(0.05)$ \\
\hline & Asontem & FA & $39.34(1.74)$ & $11.32(0.31)$ & $50.66(2.05)$ & $3.48(0.08)$ \\
\hline & & NF & $39.84(2.02)$ & $11.69(0.52)$ & $51.53(2.48)$ & $3.43(0.09)$ \\
\hline & & $\mathrm{NF}+\mathrm{O}_{3}$ & $24.45(4.94)$ & $8.18(1.27)$ & $32.63(6.10)$ & $2.90(0.03)$ \\
\hline & ANOVA & Treatment(T) & $* * *$ & $* * *$ & $* * *$ & ** \\
\hline & & Variety $(\mathrm{V})$ & $* *$ & $* *$ & ** & n.s. \\
\hline & & $\mathrm{T} \times \mathrm{V}$ & n.s. & n.s. & n.s. & n.s. \\
\hline
\end{tabular}

$\mathrm{FA}=$ Filtered air; $\mathrm{NF}=$ Non-filtered air; $\mathrm{NF}+\mathrm{O}_{3}=$ Non-filtered air plus additional ozone. Each value is the mean of three chamber replicates and the standard deviation is shown in parentheses. Two-way ANOVA: ${ }^{*} P<0.05{ }^{* *} P<0.01,{ }^{* * *} P<0.001$ means significant at $\mathrm{P}<5 \%, \mathrm{P}<1 \%$ and $\mathrm{P}<0.1 \%$, n.s. = not significant

Radical scavenging enzyme activity and antioxidants. Table 5 depicts the effect of $\mathrm{O}_{3}$ on the activities of radical scavenging enzymes, in two cowpea varieties, at vegetative (25 DAE) and reproductive (51 DAE) growth stages. At $25 \mathrm{DAE}$, the exposure to $\mathrm{O}_{3}$ significantly $(\mathrm{P}<0.05)$ reduced DHAR activity in both varieties. Asontem showed higher activities of SOD and DHAR at 25 DAE; whereas Blackeye showed a significant higher CAT activity. Interaction between gas treatment and variety was detected $(\mathrm{P}<0.05)$ in CAT activity, at 25 DAE. At 25 DAE, CAT activity of Blackeye in the $\mathrm{NF}$ and $\mathrm{NF}+\mathrm{O}_{3}$ treatments was significantly less than that in the FA treatment; while that of Asontem did not significantly differ among the gas treatments. At 51 DAE, the activities of APX, CAT, MDAR and GR were significantly affected by the exposure to $\mathrm{O}_{3}$; with no significant effects of $\mathrm{O}_{3}$ on the activities of SOD and DHAR in both varieties. The exposure to $\mathrm{O}_{3}$ significantly reduced CAT activity, whereas it increased $(\mathrm{P}<0.05)$ the activities of MDAR and GR in both varieties, also at 51 DAE. On the other hand, Asontem showed significantly higher activities of SOD, CAT and GR; whereas Blackeye showed a significantly higher activity in APX at 51 DAE. At 51 DAE. Furthermore, there was a significant interaction between gas treatment and variety in APX activity. The APX activity of Blackeye was higher in $\mathrm{NF}+\mathrm{O}_{3}$ compared to that in the FA and NF; while no significant difference in that of Asontem was detected among the gas treatments.

Table 6 presents the effect of $\mathrm{O}_{3}$ on the concentration and redox state of ascorbate in the leaves of two cowpea varieties, at vegetative ( 25 
TABLE 4. Effect of $\mathrm{O}_{3}$ on the activity and activation state of ribulose 1,5-bisphosphate carboxylase/oxygenase (Rubisco) in the leaves of two cowpea varieties at 25 and 51 days after exposure (DAE) to $\mathrm{O}_{3}$

\begin{tabular}{|c|c|c|c|c|c|}
\hline \multirow[t]{2}{*}{ Growth stage } & \multirow[t]{2}{*}{ Variety } & \multirow[t]{2}{*}{ Gas treatment } & \multicolumn{2}{|c|}{ Rubisco activity ( $\mu$ kat $\left.\mathrm{m}^{-2} \mathrm{LA}\right)$} & \multirow{2}{*}{$\begin{array}{c}\text { Activation state } \\
(\%)\end{array}$} \\
\hline & & & Initial & Total & \\
\hline \multirow[t]{9}{*}{$25 \mathrm{DAE}$} & \multirow[t]{3}{*}{ Blackeye } & FA & $21.19(5.50)$ & $27.33(5.57)$ & $76.76(7.39)$ \\
\hline & & NF & $19.41(4.84)$ & $25.79(4.96)$ & $74.49(4.92)$ \\
\hline & & $\mathrm{NF}+\mathrm{O}_{3}$ & $13.91(2.05)$ & $18.49(0.53)$ & $74.18(12.14)$ \\
\hline & \multirow[t]{3}{*}{ Asontem } & $\mathrm{FA}^{3}$ & $17.57(3.81)$ & $25.03(4.79)$ & $71.19(6.80)$ \\
\hline & & NF & $20.58(3.18)$ & $28.63(4.63)$ & $72.20(4.11)$ \\
\hline & & $\mathrm{NF}+\mathrm{O}_{3}$ & $16.59(4.45)$ & $23.48(4.00)$ & $69.93(7.96)$ \\
\hline & \multirow[t]{3}{*}{ ANOVA } & Treatment $(\mathrm{T})$ & n.s. & n.s. & n.s. \\
\hline & & Variety $(\mathrm{V})$ & n.s. & n.s. & n.s. \\
\hline & & $\mathrm{T} \times \mathrm{V}$ & n.s. & n.s. & n.s. \\
\hline \multirow[t]{9}{*}{$51 \mathrm{DAE}$} & \multirow{3}{*}{ Blackeye } & FA & $18.32(4.12)$ & $23.55(3.84)$ & $78.07(4.33)$ \\
\hline & & NF & $15.01(7.84)$ & $21.14(4.50)$ & $81.98(6.14)$ \\
\hline & & $\mathrm{NF}+\mathrm{O}_{3}$ & $11.67(1.50)$ & $14.30(2.07)$ & $81.37(2.94)$ \\
\hline & \multirow[t]{3}{*}{ Asontem } & $\mathrm{FA}$ & $22.69(5.05)$ & $27.84(6.52)$ & $80.50(1.18)$ \\
\hline & & NF & $19.20(2.79)$ & $24.85(3.64)$ & $76.37(2.91)$ \\
\hline & & $\mathrm{NF}+\mathrm{O}_{3}$ & $9.25(1.80)$ & $12.37(2.46)$ & $76.26(3.14)$ \\
\hline & \multirow[t]{3}{*}{ ANOVA } & Treatment $(\mathrm{T})$ & $* *$ & $* *$ & n.s. \\
\hline & & Variety $(\mathrm{V})$ & n.s. & n.s. & n.s. \\
\hline & & $\mathrm{T} \times \mathrm{V}$ & n.s. & n.s. & n.s. \\
\hline
\end{tabular}

$\mathrm{FA}=$ Filtered air; $\mathrm{NF}=$ Non-filtered air; $\mathrm{NF}+\mathrm{O}_{3}=$ Non-filtered air plus additional ozone. $\mathrm{DAE}=$ days after exposure Each value is the mean of three chamber replicates and the standard deviation is shown in parentheses.

Two-way ANOVA: **P $<0.01$, n.s. $=$ not significant

DAE) and reproductive (51 DAE) growth stages. At 25 DAE, reduced ascorbate (AsA) concentration, dehydroascorbate (DHA) concentration and redox state of ascorbate were not significantly affected by the exposure to $\mathrm{O}_{3}$; whereas total ascorbate concentration was significantly reduced by the exposure to $\mathrm{O}_{3}$ in the two varieties. There were no significant differences in the concentration and redox state of ascorbate between the two varieties at $25 \mathrm{DAE}$ and 51 DAE. In both varieties, no significant interaction between gas treatment and variety was detected in the concentration and redox state of ascorbate at 25 DAE and 51 DAE. At 51 DAE, the exposure to $\mathrm{O}_{3}$ significantly reduced AsA concentrations, total ascorbate concentrations and redox state of ascorbate with no significant effects of $\mathrm{O}_{3}$ on DHA concentration. On the other hand, no significant differences in the concentration and redox state of ascorbate occured between both varieties. At 51 DAE, no significant interaction between gas treatment and variety was detected in the concentration and redox state of ascorbate in both varieties.

Table 7 shows the effect of $\mathrm{O}_{3}$ on the concentration and redox state of glutathione in leaves of two cowpea varieties at vegetative (25 DAE) and reproductive (51 DAE) growth stages. At 25 DAE, reduced glutathione (GSH) concentration, oxidised glutathione (GSSG) concentration and total glutathione concentration were significantly reduced by the exposure to $\mathrm{O}_{3}$ in both varieties. On the other hand, concentrations of GSH, GSSG and total glutathione, and redox state of glutathione in Asontem were significantly higher than those in Blackeye at 25 DAE. No significant interaction between gas treatments and variety was detected 
TABLE 5. Effect of $\mathrm{O}_{3}$ on the activities of radical scavenging enzymes in the leaves of two cowpea varieties at 25 and 51 days after exposure to $\mathrm{O}_{3}$ (DAE).

\begin{tabular}{|c|c|c|c|c|c|c|c|c|}
\hline Growth stage & Variety & Gas treatment & $\begin{array}{c}\text { SOD } \\
\left(\mu k a t m^{-2} L A\right)\end{array}$ & $\begin{array}{c}\text { APX } \\
\left(\mu k a t m^{-2} L A\right)\end{array}$ & $\begin{array}{c}\text { CAT } \\
(\text { mkat m m-2 LA) }\end{array}$ & $\begin{array}{c}\text { MDAR } \\
\left(\mu k a t m^{-2} L A\right)\end{array}$ & $\begin{array}{c}\text { DHAR } \\
\left(\mu k a t m^{-2} L A\right)\end{array}$ & $\begin{array}{c}\text { GR } \\
\left(\mu k a t m^{-2} L A\right)\end{array}$ \\
\hline \multirow[t]{9}{*}{$25 \mathrm{DAE}$} & \multirow[t]{3}{*}{ Blackeye } & FA & $13.67(3.11)$ & $85.62(0.37)$ & $13.90(1.81) \mathrm{a}$ & $5.99(0.40)$ & $29.54(3.96)$ & $4.21(0.60)$ \\
\hline & & NF & $14.83(1.17)$ & $84.95(2.81)$ & $9.88(1.43) b$ & $5.74(0.31)$ & $31.55(0.79)$ & $4.04(0.34)$ \\
\hline & & $\mathrm{NF}+\mathrm{O}_{3}$ & $11.00(0.14)$ & $94.91(7.53)$ & $10.40(0.70) b$ & $6.42(0.43)$ & $23.38(1.05)$ & $4.23(0.31)$ \\
\hline & \multirow[t]{3}{*}{ Asontem } & FA & $15.76(0.52)$ & $79.91(4.45)$ & $5.65(1.19) \mathrm{C}$ & $6.01(0.61)$ & $45.11(1.59)$ & $4.31(0.29)$ \\
\hline & & NF & $16.66(0.42)$ & $85.28(27.86)$ & $5.36(0.34) \mathrm{c}$ & $6.31(0.90)$ & $47.43(3.92)$ & $4.21(0.38)$ \\
\hline & & $\mathrm{NF}+\mathrm{O}_{3}$ & $14.35(3.88)$ & $80.54(13.47)$ & $6.39(1.34) \mathrm{c}$ & $6.52(0.22)$ & $39.98(6.28)$ & $4.62(058)$ \\
\hline & \multirow[t]{3}{*}{ ANOVA } & Treatment $(\mathrm{T})$ & n.s. & n.s. & * & n.s. & $* *$ & n.s. \\
\hline & & Variety $(\mathrm{V})$ & * & n.s. & $* * *$ & n.s. & $* * *$ & n.s. \\
\hline & & $\mathrm{T} \times \mathrm{V}$ & n.s. & n.s. & * & n.s. & n.s. & n.s. \\
\hline \multirow[t]{9}{*}{$51 \mathrm{DAE}$} & \multirow[t]{3}{*}{ Blackeye } & FA & $12.78(3.32)$ & $57.92(13.58) b$ & $7.16(0.42)$ & $4.32(0.33)$ & $20.77(3.06)$ & $2.00(0.10)$ \\
\hline & & NF & $12.74(1.61)$ & $58.92(7.02) b$ & $6.89(0.71)$ & $4.41(0.57)$ & $22.01(0.71)$ & $2.38(0.31)$ \\
\hline & & $\mathrm{NF}+\mathrm{O}_{3}$ & $11.56(0.84)$ & $111.42(11.91) a$ & $5.61(0.58)$ & $8.28(0.23)$ & $19.49(3.25)$ & $2.57(0.34)$ \\
\hline & \multirow[t]{3}{*}{ Asontem } & FA & $15.29(2.31)$ & $55.96(5.32) b$ & $10.56(2.02)$ & $5.49(0.39)$ & $24.10(4.09)$ & $3.03(0.42)$ \\
\hline & & NF & $15.07(0.58)$ & $57.71(6.06) b$ & $10.49(1.10)$ & $5.24(0.42)$ & $21.63(1.86)$ & $3.20(0.23)$ \\
\hline & & $\mathrm{NF}+\mathrm{O}_{3}$ & $14.01(0.92)$ & $74.89(15.47) b$ & $7.41(1.02)$ & $7.63(2.34)$ & $19.50(1.52)$ & $4.41(0.57)$ \\
\hline & \multirow[t]{3}{*}{ ANOVA } & Treatment $(\mathrm{T})$ & n.s. & *** & $* *$ & $* * *$ & n.s. & ** \\
\hline & & Variety $(\mathrm{V})$ & * & * & $* * *$ & n.s. & n.s. & $* * *$ \\
\hline & & $\mathrm{T} \times \mathrm{V}$ & n.s. & * & n.s. & n.s. & n.s. & n.s. \\
\hline
\end{tabular}

$\mathrm{FA}=$ Filtered air; $\mathrm{N}=$ : Non-Filtered air; $\mathrm{NF}+\mathrm{O}=$ Non-filtered air plus additional ozone. Each value is the mean of three chamber replicates and the standard deviation is shown in parentheses. Twoway ANOVA: ${ }^{*}<<0.05,{ }^{* *} P<0.01,{ }^{* * *} P<0.001$ represents significant at $\mathrm{P}<5 \%, P<1 \%$ and $\mathrm{P}<0.1 \%$, n.s. = not significant. When significant interaction between $\mathrm{O}_{3}$ and variety was detected, Tukey's HSD test was performed to identify significant differences among the 6 treatments. Values with different letters are significantly different at $P<0.05$ 
TABLE 6. Effect of $\mathrm{O}_{3}$ on reduced ascorbate (AsA) concentration, dehydroascorbate (DHA) concentration, total ascorbate concentration and redox state of ascorbate in the leaves of two cowpea varieties at 25 and 51 days after exposure (DAE) to $\mathrm{O}_{3}$

\begin{tabular}{|c|c|c|c|c|c|c|}
\hline Growth stage & Variety & Treatment & 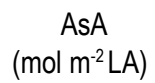 & $\begin{array}{c}\text { DHA } \\
\left(\mathrm{mol} \mathrm{m} \mathrm{m}^{-2} \mathrm{LA}\right)\end{array}$ & $\begin{array}{c}\text { Total } \\
\left(\mathrm{mol} \mathrm{m} \mathrm{m}^{-2} \mathrm{LA}\right)\end{array}$ & $\begin{array}{c}\text { Redox state } \\
(\%)\end{array}$ \\
\hline \multirow[t]{9}{*}{$25 \mathrm{DAE}$} & Blackeye & FA & $1.62(0.47)$ & $0.23(0.07)$ & $1.85(0.43)$ & $87.34(5.37)$ \\
\hline & & NF & $1.37(0.23)$ & $0.17(0.06)$ & $1.55(0.19)$ & $88.92(3.93)$ \\
\hline & & $\mathrm{NF}+\mathrm{O}_{3}$ & $1.08(0.14)$ & $0.11(0.04)$ & $1.18(0.17)$ & $91.47(1.65)$ \\
\hline & Asontem & $\mathrm{FA}$ & $1.33(0.10)$ & $0.15(0.05)$ & $1.48(0.15)$ & $88.01(5.77)$ \\
\hline & & NF & $1.50(0.05)$ & $0.17(0.05)$ & $1.67(0.05)$ & $89.51(3.11)$ \\
\hline & & $\mathrm{NF}+\mathrm{O}_{3}$ & $1.26(0.12)$ & $0.15(0.06)$ & $1.41(0.09)$ & $88.17(6.82)$ \\
\hline & ANOVA & Treatment $(\mathrm{T})$ & n.s. & n.s. & * & n.s. \\
\hline & & Variety $(\mathrm{V})$ & n.s. & n.s. & n.s. & n.s. \\
\hline & & $\mathrm{T} \times \mathrm{V}$ & n.s. & n.s. & n.s. & n.s. \\
\hline \multirow[t]{9}{*}{$51 \mathrm{DAE}$} & Blackeye & FA & $1.13(0.23)$ & $0.14(0.02)$ & $1.28(0.21)$ & $88.04(4.12)$ \\
\hline & & NF & $1.22(0.18)$ & $0.14(0.05)$ & $1.36(0.20)$ & $89.39(2.74)$ \\
\hline & & $\mathrm{NF}+\mathrm{O}_{3}$ & $0.75(0.10)$ & $0.14(0.02)$ & $0.89(0.12)$ & $84.33(0.17)$ \\
\hline & Asontem & FA & $1.36(0.17)$ & $0.21(0.07)$ & $1.58(0.24)$ & $87.00(2.42)$ \\
\hline & & NF & $1.17(0.16)$ & $0.13(0.02)$ & $1.29(0.16)$ & $89.38(2.72)$ \\
\hline & & $\mathrm{NF}+\mathrm{O}_{3}$ & $0.67(0.14)$ & $0.13(0.01)$ & $0.80(0.14)$ & $82.39(5.58)$ \\
\hline & ANOVA & Treatment(T) & $* * *$ & n.s. & $* * *$ & * \\
\hline & & Variety $(\mathrm{V})$ & n.s. & n.s. & n.s. & n.s. \\
\hline & & $\mathrm{T} \times \mathrm{V}$ & n.s. & n.s. & n.s. & n.s. \\
\hline
\end{tabular}

$\mathrm{FA}=$ Filtered air; $\mathrm{NF}=$ Non-filtered air; $\mathrm{NF}+\mathrm{O}_{3}=$ Non-filtered air plus additional ozone. Each value is the mean of three growthchamber replicates and the standard deviation is shown in parentheses. Two-way ANOVA: ${ }^{*} P<0.05,{ }^{* \star *} P<0.001$, n.s. $=$ not significant

in the concentrations and redox state of glutathione at 25 DAE. At 51 DAE, there were significant interactions between gas treatment and variety in GSH concentration, GSSG concentration and total glutathione concentration. In Blackeye, no significant differences in the GSH concentration, GSSG concentration and total glutathione concentration were detected among the gas treatments at 51 DAE. In Asontem, however, GSH concentration, GSSG concentration and total glutathione concentrations in the $\mathrm{NF}$ and $\mathrm{NF}+\mathrm{O}_{3}$ treatments were significantly less than those in the FA treatment at 51 DAE. On the other hand, there was no significant effect of $\mathrm{O}_{3}$ on the redox state of glutathione at $51 \mathrm{DAE}$. No significant differences in the concentrations and redox state of glutathione were detected between both varieties at 51 DAE. Furthermore, no significant interaction between gas treatment and variety was detected in the redox state of glutathione at 51 DAE.

\section{DISCUSSION}

Photosynthetic components of two cowpea varieties. In the leaves of cowpea exposed to $\mathrm{O}_{3}$, the decrease in quantum yield of PSII electron transport, the increase in the proportion of the closed PSII reaction centres, and the increase of $N P Q$ may be together part of a down-regulation mechanism of photosynthetic process. Dissipation of excess energy absorbed by photosynthetic apparatus prevents photoxidative damage that occurs when excited chlorophyll molecules improperly transfer their higher energy state to oxygen or neighboring molecules and convert them into reactive molecules or toxic 
TABLE 7. Effect of $\mathrm{O}_{3}$ on reduced glutathione (GSH) concentration, oxidized glutathione (GSSG) concentration, total glutathione concentration and redox state of glutathione in the leaves of two cowpea varieties at 25 and 51 days after exposure to $\mathrm{O}_{3}$ (DAE)

\begin{tabular}{|c|c|c|c|c|c|c|}
\hline Growth stage & Variety & Treatment & $\begin{array}{c}\text { GSH } \\
\left(\mathrm{mmol} \mathrm{m} \mathrm{m}^{-2} \mathrm{LA}\right)\end{array}$ & 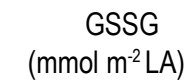 & 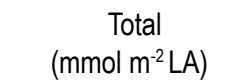 & $\begin{array}{c}\text { Redox state } \\
(\%)\end{array}$ \\
\hline \multirow[t]{9}{*}{$25 \mathrm{DAE}$} & Blackeye & FA & $385.75(23.53)$ & $7.30(0.69)$ & $393.05(24.19)$ & $98.14(0.08)$ \\
\hline & & NF & $362.10(28.19)$ & $6.95(0.61)$ & $369.05(28.81)$ & $98.12(0.02)$ \\
\hline & & $\mathrm{NF}+\mathrm{O}_{3}$ & $294.07(16.46)$ & $5.55(0.33)$ & $299.62(16.77)$ & $98.14(0.03)$ \\
\hline & Asontem & FA & $420.77(13.68)$ & $7.87(0.30)$ & $428.64(13.98)$ & $98.17(0.02)$ \\
\hline & & NF & 443.54 (18.39) & $8.17(0.17)$ & $451.71(18.56)$ & $98.18(0.03)$ \\
\hline & & $\mathrm{NF}+\mathrm{O}_{3}$ & $402.91(40.61)$ & $7.43(0.76)$ & $410.34(41.37)$ & $98.19(0.02)$ \\
\hline & ANOVA & Treatment $(\mathrm{T})$ & $* *$ & $* *$ & $* *$ & n.s. \\
\hline & & Variety $(\mathrm{V})$ & *** & $* * *$ & *** & * \\
\hline & & $\mathrm{T} \times \mathrm{V}$ & n.s. & n.s. & n.s. & n.s. \\
\hline \multirow[t]{9}{*}{$51 \mathrm{DAE}$} & Blackeye & FA & 327.41 (15.34) abc & $6.41(0.15) a b c$ & 333.81 (15.49) abc & $98.08(0.04)$ \\
\hline & & NF & 353.99 (22.29) ab & $6.88(0.44) a b$ & $360.87(22.73) a b$ & $98.09(0.01)$ \\
\hline & & $\mathrm{NF}+\mathrm{O}_{3}$ & $301.35(38.71) b c$ & $5.81(0.82) b c$ & $307.16(39.53) b c$ & $98.11(0.02)$ \\
\hline & Asontem & FA & $368.97(19.00) a$ & $7.19(0.35) a$ & $376.16(19.35) \mathrm{a}$ & $98.10(0.01)$ \\
\hline & & $N F$ & $318.63(22.32) b c$ & $6.23(0.46) b c$ & $324.86(22.79) b c$ & $98.08(0.01)$ \\
\hline & & $\mathrm{NF}+\mathrm{O}_{3}$ & $275.89(19.62) \mathrm{c}$ & $5.31(0.39) \mathrm{c}$ & $281.21(19.96) \mathrm{C}$ & $98.11(0.06)$ \\
\hline & ANOVA & Treatment $(\mathrm{T})$ & ** & ** & ** & n.s. \\
\hline & & Variety $(\mathrm{V})$ & n.s. & n.s. & n.s. & n.s. \\
\hline & & $\mathrm{T} \times \mathrm{V}$ & * & * & * & n.s. \\
\hline
\end{tabular}

$\mathrm{FA}=$ Filtered air; $\mathrm{NF}=$ Non-filtered air; $\mathrm{NF}+\mathrm{O}_{3}=$ Non-filtered air plus additional ozone. Each value is the mean of three growthchamber replicates and the standard deviation is shown in parentheses. Two-way ANOVA: ${ }^{*} P<0.05,{ }^{* *} P<0.01,{ }^{* * *} P<0.001$, n.s. $=$ not significant. When significant interaction between $\mathrm{O}_{3}$ and variety was detected, Tukey's HSD test was performed to identify significant differences among the 6 treatments. Values with different letters are significantly different at $P<0.05$.

radicals (Asada, 1999; Heber et al., 2001; Mullineaux and Karpinski, 2002). Because Rubisco activity was significantly reduced by the exposure to $\mathrm{O}_{3}$ at the reproductive growth stage (Table 4), this down regulation mechanism could help maintain electron flux in equilibrium, with the decreased NADPH and ATP demand of the Calvin cycle; thus lowering the probability of ROS formation from electrons not reaching the end acceptors (Wilhelm and Selmar, 2011).

The $\mathrm{O}_{3}$-induced reduction in chlorophyll $a / b$ ratio in the $\mathrm{NF}+\mathrm{O}_{3}$ treatment suggests that either chlorophyll $a$ was more readily degraded than chlorophyll $b$, or the synthesis of new chlorophyll $a$ was reduced by the exposure to $\mathrm{O}_{3}$ (Table 3). In contrast, Malaiyandi and Natarajan (2014) reported that acute exposure (i.e., 15 min twice a day) of cowpea to $\mathrm{O}_{3}$ at $60 \mathrm{ppb}$, increased total chlorophyll concentration. The contrasting results could be due to the different exposure methods (i.e., long-term exposure in open-top chamber and short-term exposure in closed chamber). Because many studies have reported that $\mathrm{O}_{3}$-mediated decline in photosynthetic pigments, chlorophylls a and b (Morgan et al., 2003; Leitao et al., 2008), long-term exposure to ambient levels of $\mathrm{O}_{3}$ could cause reduction in chlorophyll concentration in the leaves of cowpea cultivated in the field.

Chlorophyll plays an important role in capturing light to power photosystems I and II, which provides energy-rich molecules (ATP and NADPH) to the Calvin cycle (Salvatori et al., 2013). On the other hand, it has been reported 
that $\mathrm{O}_{3}$-induced reduction in photosynthetic capacity is caused primarily by a decrease in the maximum in vivo rate of Rubisco carboxylation, due to a reduction in the activity and/or quantity of Rubisco (Long and Naidu, 2002; Biswas and Jiang, 2011). Therefore, the $\mathrm{O}_{3}$-induced reductions in Rubisco activity and chlorophyll concentration (Tables 3 and 4) are considered to be the limiting factors which contributed to the $\mathrm{O}_{3}$-induced reduction in net photosynthetic rate in both varieties.

Radical scavenging system. In the leaves of Asontem, activities of SOD and DHAR and concentration of glutathione were higher than those of Blackeye (Tables 5 and 7). This variety difference in the detoxification capacity could confer the $\mathrm{O}_{3}$ tolerance on Asontem, because the difference in the $\mathrm{O}_{3}$ sensitivity among species and cultivars could be explained by the $\mathrm{O}_{3}$ induced change in detoxification capacity (Noctor and Foyer, 1998). However, there was no significant difference in the $\mathrm{O}_{3}$ sensitivity of photosynthetic parameters (Tables 2, 3 and 4). Therefore, higher detoxification capacity of ROS observed in Asontem was not enough to mitigate detrimental effects of ambient levels of $\mathrm{O}_{3}$ on photosynthesis and it's components and thus did not confer the $\mathrm{O}_{3}$ tolerance on Asontem.

In our study, both varieties showed different response in their $\mathrm{H}_{2} \mathrm{O}_{2}$ scavenging abilities at both growth stages. Blackeye showed an $\mathrm{O}_{3}$-induced reduction in CAT activity at both growth stages whereas in Asontem a reduction was observed at the reproductive period. Besides, the exposure to $\mathrm{O}_{3}$ significantly increased APX activity in Blackeye at reproductive period whereas in Asontem no difference was observed at both growth stages (Table 5). Both APX and CAT catalyse the reaction of scavenging $\mathrm{H}_{2} \mathrm{O}_{2}$ with electron donor (AsA) and without it, respectively (Aebi, 1984; Miyake, 2010). Thus, the $\mathrm{O}_{3}$-induced reduction in CAT activity observed in Blackeye and Asontem and the increase in APX activity in Blackeye suggests that, in the leaves of cowpea exposed to $\mathrm{O}_{3}$, APX rather than CAT, played an important role in scavenging $\mathrm{H}_{2} \mathrm{O}_{2}$ (Table 5). However, because photosynthetic parameters, such as net photosynthetic rate and Rubisco activity, were significantly reduced by the exposure to $\mathrm{O}_{3}$ in both varieties (Tables 2, 3 and 4), APX activity observed in this study was insufficient to deter the detrimental effects of ambient levels of $\mathrm{O}_{3}$ on net photosynthesis in the leaves of cowpea.

In both cowpea varieties at reproductive growth stage, significant increase in MDAR activity was observed in response to $\mathrm{O}_{3}$ exposure (Table 5). This response could be considered as one of responses to $\mathrm{O}_{3}$ exposure to maintain redox state of ascorbate and/or provide AsA for scavenging $\mathrm{H}_{2} \mathrm{O}_{2}$ in the leaves of cowpea, because oxidised AsA (MDA) can be reduced by the action of MDAR (Miyake, 2010). The MDA can also be reduced by its disproportionation to AsA and DHA, and resultant DHA is then reduced to AsA by oxidation of GSH catalysed by DHAR (Miyake, 2010). GSH in turn is regenerated from oxidised GSH (i.e., GSSG) by GR (Davey et al., 2000; Miyake, 2010). At the reproductive growth stage, therefore, the $\mathrm{O}_{3}$ induced increase in GR activity and high glutathione redox state maintained in the $\mathrm{O}_{3}$ treatments in the leaves of cowpea can be considered as one of the responses to $\mathrm{O}_{3}$ exposure to maintain redox state of ascorbate and/or provide AsA for scavenging $\mathrm{H}_{2} \mathrm{O}_{2}$ (Tables 5 and 7), although the exposure to $\mathrm{O}_{3}$ did not significantly increase DHAR activity (Table 5). However, the redox state of ascorbate and AsA concentration were significantly decreased by the exposure to $\mathrm{O}_{3}$ at the reproductive growth stage (Table 6). These results suggest that the $\mathrm{O}_{3}$ induced increase in activities of MDAR and GR and high redox state of glutathione in the leaves of cowpea was not sufficient to maintain the redox state of ascorbate, which might result in the insufficient detoxification capacity of $\mathrm{H}_{2} \mathrm{O}_{2}$ by the action of APX using AsA to avoid the detrimental effects of $\mathrm{O}_{3}$ on photosynthetic parameters.

\section{CONCLUSION}

The exposure to ambient levels of $\mathrm{O}_{3}$ reduces photosynthetic components of two African cowpea varieties (Blackeye and Asontem), thus contributing to the reduction in net photosynthetic rate, with no significant difference in the sensitivity to $\mathrm{O}_{3}$ between the two varieties. Although ascorbate peroxidase, monodehydro- 
ascorbate reductase and glutathione reductase play important roles in scavenging reactive oxygen species induced by the exposure to $\mathrm{O}_{3}$ in the leaves, radical scavenging ability of these enzymes is not enough to prevent detrimental effects of ambient levels of $\mathrm{O}_{3}$ on photosynthesis in both varieties.

\section{ACKNOWLEDGEMENT}

The authors are grateful to Professor Ryo Funada (Institute of Agriculture, Tokyo University of Agriculture and Technology) and Professor Yoshiharu Wada (Faculty of Agriculture, Utsunomiya University) for their invaluable suggestions. The authors thank Yu Taniguchi, Lijuan Sun, Eri Kubota and Dr. Mohammed Zia Uddin Kamal (Tokyo University of Agriculture and Technology) for technical support. The first author is grateful to the Education Programme for Field-Oriented Leaders in Asia and Africa (FOLENS) of Tokyo University of Agriculture and Technology for financial support.

\section{REFERENCES}

Addo-Quaye, A.A., Darkwa, A.A. and Ampiah, M.K.P. 2011. Performance of three cowpea (Vigna unguiculata (L) Walp) varieties in two agro-ecological zones of the Central Region of Ghana II: Grain yield and its components. ARPN Journal of Agricultural and Biological Science 6(2): 34-42.

Aebi, H. 1984. Catalase in vitro. Methods in Enzymology 105: 121-126.

Ainsworth, E.A., Yendrek, C.R., Sitch, S., Collins, W.J. and Emberson, L.D. 2012. The effects of tropospheric ozone on net primary productivity and implications for climate change. Annual Review of Plant Biology 63: 637-661.

Asada, K. 1999. The water-water cycle in chloroplasts: Scavenging of active oxygens and dissipation of excess photons. Annual Review of Plant Biology 50(1): 601-639.

Baier, M., Kandlbinder A, Golldack, D. and Dietz, K.J. 2005. Oxidative stress and ozone: perception, signaling and response. Plant, Cell \& Environment 28(8): 1012-1020.
Barnes, J.D., Balaguer, L., Manrique, E., Elvira, S., and Davison, A.W. 1992. A reappraisal of the use of DMSO for the extraction and determination of Chlorophylls a and $b$ in lichens and higher plants. Environmental and Experimental Botany 32(2): 85-100.

Biswas, D.K. and Jiang, G.M. 2011. Differential drought-induced modulation of ozone tolerance in winter wheat species. Journal of Experimental Botany 62: 4153-4162.

Blokhina, O., Virolainen, E. and Fagerstedt, K.V. 2003. Antioxidants, oxidative damage and oxygen deprivation stress: a review. Annals of Botany 91(2): 179-194.

Booker, F., Muntifering R., McGrath, M., Burkey, K., Decoteau, D., Fiscus, E., Manning, W., Krupa, S., Chappelka, A. and Grantz, D. 2009. The ozone component of global change: Potential effects on agricultural and horticultural plant yield, product quality and interactions with invasive species. Journal of Integrative Plant Biology 51(4): 337-351.

Cheng, F.Y., Burkey, K.O., Robbinson, J.M. and Booker, F. L. 2007. Leaf extracellular ascorbate in relation to $\mathrm{O}_{3}$ tolerance of two soyabean cultivars. Environmental Pollution 150(3): 355-362.

Davey, M.W., Montagu, M.V., Inzé, D., Sanmartin, M., Kanellis, A., Smirnoff, N., BenzieIris, J.J., Strain, J.J., Favell, D. and Fletcher, J. 2000. Plant L-ascorbic acid: chemistry, function, metabolism, bioavailability and effects of processing. Journal of the Science of Food and Agriculture 80(7): 825-860.

Emberson, L.D., Kitwiroon, N., Beevers, S., Buker, P. and Cinderby, S. 2013. Scorched Earth: How will changes in the strength of the vegetation sink to ozone deposition affect human health and ecosystems? Atmospheric Chemistry and Physics 13(14):6741-6755.

FAOSTAT. 2012. Food and Agriculture Organization database. Available online at: http://faostat.fao.org.

Fuhrer, J. 2009. Ozone risk for crops and pastures in present and future climates. Naturwissenschaften 96(2): 173-194.

Heath, R.L. 2008. Modification of the biochemical pathways of plants induced by ozone: What are the varied routes to change? Environmental Pollution 155(3): 453-463. 
Heber, U., Bukhov, N.G., Shuvalov, V.A., Kobayashi, Y. and Lange, O.L. 2001. Protection of the photosynthetic apparatus against damage by excessive illumination in homoiohydric leaves and poikilohydric mosses and lichens. Journal of Experimental Botany 52(363):1999-2006.

Inada, H., Yamaguchi, M., Satoh, R., Hoshino, D., Nagasawa, A., Negishi, Y., Nouchi, I., Kobayashi, K. and Izuta, T. 2008. Effects of ozone on photosynthetic components and radical scavenging system in leaves of rice (Oryza sativa L.). Journal of Agricultural Meteorology 64(4):243-255.

Langyintuo, A.S., Lowenberg-Deboer, J., Faye, M., Lambert, D., Ibro, G., Moussa, B., Kergna, A., Kuswaha, S., Musa, S. and Ntoukam, G. 2003. Cowpea supply and demand in West and Central Africa. Field Crops Research 82(2):215-231.

Leitao, L., Dizengremel, P. and Biolley, J. P. 2008. Foliar $\mathrm{CO}_{2}$ fixation in bean (Phaseolus vulgaris L.) submitted to elevated ozone: Distinct changes in Rubisco and PEPc activities in relation to pigment content. Ecotoxicology and Environmental Safety 69(3):531-540.

Long, S.P. and Naidu, S.L. 2002. Effects of oxidants at the biochemical, cell and physiological levels, with particular reference to ozone. In: Bell, J.N.B. and Treshow, M. (Eds.), Air Pollution and Plant Life, John Wiley \& Sons Ltd., England. pp. 69-88.

Malaiyandi, M. and Natarajan, M. 2014. Impact of ozone on morphological, physiological, and biochemical changes in cowpea (Vigna unguiculata (L.) Walp.). Ozone: Science and Engineering 36(1):36-42.

Miyake, C. 2010. Alternative electron flows (water-water cycle and cyclic electron flow around PSI) in photosynthesis: Molecular mechanisms and physiological functions. Plant and Cell Physiology 51(12):1951-1963.

Morgan, P.B., Ainsworth, E.A. and Long, S.P. 2003. How does elevated ozone impact soybean? A meta-analysis of photosynthesis, growth and yield. Plant, Cell and Environment 26(8): 1317-1328.

Mullineaux, P. and Karpinski, S. 2002. Signal transduction in response to excess light:
Getting out of the chloroplast. Current Opinion in Plant Biology 5(1):43-48.

Noctor, G. and Foyer, C.H., 1998. Ascorbate and glutathione: keeping active oxygen under control. Annual review of plant biology 49(1): 249-279.

Pell, E.J., Schlagnhaufer, C.D. and Arteca, R.N. 1997. Ozone-induced oxidative stress: mechanisms of action and reaction. Physiologia Plantarum 100(2):264-273

Pina, J.M. and Moraes, R.M. 2010. Gas exchange, antioxidants and foliar injuries in saplings of a tropical woody species exposed to ozone. Ecotoxicology and Environmental Safety 73(4):685-691.

Salvatori, E., Fusaro, L., Mereu, S., Bernardini, A., Puppi, G. and Manes, F. 2013. Different $\mathrm{O}_{3}$ response of sensitive and resistant snap bean genotypes (Phaseolus vulgaris L.): The key role of growth stage, stomatal conductance, and PSI activity. Environmental and Experimental Botany 87:79-91.

Sauvage, B., Gheusi, F., Thouret, V., Cammas, J.P., Duron, J., Escobar, J., Mari, C., Mascart, P. and Pont, V. 2007. Medium-range mid tropospheric transport of ozone and precursors over Africa: Two numerical case studies in dry and wet seasons, Atmospheric Chemistry and Physics 7(20):5357-5370.

Tetteh, R., Yamaguchi, M., Wada, Y., Funada, R. and Izuta, T. 2015. Effects of ozone on growth, net photosynthesis and yield of two African varieties of Vigna unguiculata. Environmental Pollution 196:230-238.

Tissue, D.T., Thomas, R. B. and Strain, B.R. 1993. Long-term effects of elevated $\mathrm{CO}_{2}$ and nutrients on photosynthesis and Rubisco in loblolly pine seedlings. Plant Cell and Environment 16: 859-865.

Umponstira, C., Pimpa, W. and Nanegrungsun, S. 2006. Physiological and biochemical responses of cowpea (Vigna unguiculata (L.) Walp) to ozone. Songklanakarin Journal of Science and Technology 28: 861-869.

Wilhelm, C. and Selmar, D. 2011. Energy dissipation is an essential mechanism to sustain the viability of plants: The physiological limits of improved photosynthesis. Journal of Plant Physiology 168(2):79-87. 
World Meteorological Organisation (WMO). Zeng, B., Wang, F.J., Zhu, C. and Sun, Z.X. 2008. 2011. Ozone Map. In: Climate Change and Food Security. Available at: www.climate Effect of ascorbate-glutathione (AsA-GSH) change-foodsecurity.org cycle on $\mathrm{Hg}^{2+}$-tolerance in rice mutant. Acta Agronomica Sinica 34: 823-830. 